\title{
Bactericidal Potential of Extract Citrus Hystrix D.C.Leaf Powder on Staphylococcus aureus and Salmonella typhi
}

\author{
Elfira Maulidah, Anny Thuraidah, Leka Lutpiatina \\ Medical Laboratory Technology Banjarmasin Health Polytechnic \\ Mistar Cokrokusumo Street 4a Banjarbaru Indonesia \\ e-mail: annythura2014@gmail.com
}

\begin{abstract}
Infectious diseases can be caused by bacteria such as Staphylococcus aureus and Salmonella typhi. Treatment of infectious diseases can use antibiotics. However, antibiotics can cause side effects on users. Kuit Lime leaf (Citrus hystrix D.C.) contains secondary metabolites such as alkaloids, steroids, triterpenoids, tannins, and flavonoids used as antibacterial. This study aimed to determine the bactericidal potential of the kuit lime leaf extract powder on Staphylococcus aureus and Salmonella typhi. The type of research used is the experiment, and the research design used is the Posttest Only Control Group Design. The antibacterial activity test used was the liquid dilution of MIC and MBC. The results showed the MIC of Staphylococcus aureus and Salmonella typhi was $180 \mathrm{mg} / \mathrm{mL}$ and $120 \mathrm{mg} / \mathrm{mL}$, while the MBC results against Staphylococcus aureus and Salmonella typhi are $190 \mathrm{mg} / \mathrm{mL}$ and $130 \mathrm{mg} / \mathrm{mL}$. Data analysis in this research conducted descriptively. Based on descriptive analysis, it concluded that the bactericidal potential of the powdered extract of kuit lime against Staphylococcus aureus is at a concentration of $190 \mathrm{mg} / \mathrm{mL}$ and Salmonella typhi at a concentration of $130 \mathrm{mg} / \mathrm{mL}$.
\end{abstract}

Keywords: Citrus hystrix D.C, Staphylococcus aureus, Salmonella typhi

Copyright (C) 2021 Jurnal Skala Kesehatan. Politeknik Kesehatan Banjarmasin All rights reserved

Corresponding Author:

Anny Thuraidah,

Medical Laboratory Technology Poltekkes Kemenkes Banjarmasin. Mistar

Cokrokusumo Street 4a Banjarbaru Indonesia 70714.

E-mail: annythura2014@gmail.com 


\section{INTRODUCTION}

Infectious diseases caused by tuberculosis ${ }^{1}$, Staphylococcus aureus and Salmonella thypi are the main obstacles in Indonesia, besides the problem of bacterial environmental contamination such as Staphylococcus aureus ${ }^{2}$ and Bacillus ${ }^{3}$. Staphylococcus aureus is a floranormal on the skin, respiratory tract, and human digestive tract. Infectious diseases caused by these bacteria include acne and ulcers. A bacterial infection characterized by infection of festering wounds ${ }^{4}$. Data from the Republic of Indonesia Ministry of Health in 2016 skin diseases and subcutaneous tissue ranks third out of the ten most diseases in outpatients in hospitals in Indonesia with 122,076 new case visits, and in 2015 there were 70,338 cases. While Salmonella typhi is a bacterium that causes typhoid fever ${ }^{5}$, WHO data for 2018 cases of typhoid fever worldwide are estimated to be $21,000,000$ cases with 128,000 to 161,000 deaths each year, the most cases are in South and Southeast Asia6.

One of the antibiotics used as antimicrobials that can inhibit or kill both gramnegative and positive bacteria is chloramphenicol ${ }^{7}$. Chloramphenicol has side effects such as blood dyscrasias, optic neuritis, and possibly spinal cord depression can cause aplastic anemia ${ }^{8}$. To reduce these side effects, treatment with herbal medicines is an alternative. Indonesia is a country rich in herbal plants as medicinal plants such as Cinnamomum burmannii ${ }^{9}$, Eleutherine palmifollia (L) Merr ${ }^{10}$, Hibiscus sabdariffa L. ${ }^{11}$ Ocimum basilicum Linn ${ }^{12}$, Citrus hystrix D.C. ${ }^{13}$. Citrus hystrix D.C. is commonly used as a flavoring and kitchen spice but also can be used as traditional medicine ${ }^{14}$. Research in 2017, said that the leaves of kuit lime (Citrus hystrix D.C.) contain secondary metabolites such as alkaloids, steroids, triterpenoids, tannins, and flavonoids that can be used as antibacterial ${ }^{15}$. According to research in 2010 states that the methanol extract of lime leaves (Citrus aurantifolia Swingle) against some microbes with a concentration of $1.6 \% ; 0.8 \% ; 0.4 \% ; 0.2 \% ; 0.1 \%$; and $0.05 \%$, the results of MIC Staphylococcus aureus and Salmonella typhi at each concentration formed turbidity, while MBC Staphylococcus aureus at a concentration of $0.4 \%$ and Salmonella typhi at a concentration of $1.6 \%{ }^{16}$.

Research conducted by Yuliani et al. showed that essential oils of kaffir lime leaves (Citrus hystrix) against Staphylococcus aureus and Escherichia coli obtained the results of Minimum Inhibitory Concentration (MIC) of Staphylococcus aureus namely $1 \%$ and Escherichia coli $0.0625 \%$. While the Minimum Kill Concentration (MBC) of Staphylococcus aureus is $2 \%$ and Escherichia coli $0.0625 \%{ }^{17}$. Another study conducted by Uda., et al., revealed that extracts of kaffir lime leaves (Citrus hystrix) with concentrations of $5 \mathrm{mg} / \mathrm{mL}, 10 \mathrm{mg} / \mathrm{mL}, 20 \mathrm{mg} / \mathrm{mL}$ and $30 \mathrm{mg} / \mathrm{mL}$ using diffusion method showed antibacterial activity Bacillus subtilis with $6 \mathrm{~mm}$ inhibition zone diameter; $7.06 \mathrm{~mm} ; 9.34 \mathrm{~mm}$; and $10.68 \mathrm{~mm}^{18}$. This study aims to determine the effectiveness of the extract of Kuit (Citrus hystrix D.C.) leaf on the growth of Staphylococcus aureus and Salmonella typhi.

\section{MATERIALS AND METHODS}

This type of research is an experiment using the Posttest Only Control Group Design with the method of checking the minimum inhibitory concentration (MIC) and the minimum kill concentration (MBC) of lime leaf extract powder on Staphylococcus aureus namely $130 \mathrm{mg} / \mathrm{mL}, 140 \mathrm{mg} / \mathrm{mL}, 150 \mathrm{mg} / \mathrm{mL}, 160 \mathrm{mg} / \mathrm{mL}, 170 \mathrm{mg} / \mathrm{mL}$, $180 \mathrm{mg} / \mathrm{mL}, 190 \mathrm{mg} / \mathrm{mL}$, and $200 \mathrm{mg} / \mathrm{mL}$, whereas for Salmonella typhi that is 90 $\mathrm{mg} / \mathrm{mL}, 100 \mathrm{mg} / \mathrm{mL}, 110 \mathrm{mg} / \mathrm{mL}, 120 \mathrm{mg} / \mathrm{mL} \mathrm{mL}, 130 \mathrm{mg} / \mathrm{mL}, 140 \mathrm{mg} / \mathrm{mL}$ and $150 \mathrm{mg} / \mathrm{mL}$ were then compared with the negative control group namely sterile TSB, 
control of Citrus hystrix leaf powder extract, and positive control namely chloramphenicol, with 4 times repetitions. This research conducted in Maret 2020 at the Microbiology Laboratory of Health Analyst Polytechnic Health Banjarmasin but for determination and phytochemical test at Lambung Mangkurat University Banjarmasin.

Citrus hystrix leaves that picked are dried in the open air and covered with a thin black cloth to avoid being protected from direct sunlight until dry smoothed with a blender to reduce the surface area of the simplicia with a 60 mesh sieve so that the contact surface area with more significant solvents ${ }^{19}$ then processed into extracts using maceration method using $96 \%$ ethanol solvent. The extract obtained was added aerosil to be an extract powder. Based on the calculation of wet weight yield obtained $34.98 \%$, and the yield of Citrus hystrix leaves $33.33 \%$.

\section{RESULT AND DISCUSSION}

Table 1. Phytochemical Test Results for the content of secondary metabolites in the leaves of Citrus hystrix

\begin{tabular}{|c|c|c|c|}
\hline No. & Parameter & Test & Result \\
\hline 1. & Alkaloid & HCL, Mayer & Positive, orange precipitate \\
\hline 2. & Alkaloid & $\begin{array}{l}\text { HCL, } \\
\text { Dragendroff }\end{array}$ & Positive, brown precipitate \\
\hline 3. & Alkaloid & $\begin{array}{l}\text { HCL, } \\
\text { Wagner }\end{array}$ & Positive, white precipitate \\
\hline $\begin{array}{l}4 . \\
5 .\end{array}$ & $\begin{array}{l}\text { Flavonoid } \\
\text { Saponin } \\
\text { Steroid }\end{array}$ & $\begin{array}{l}\mathrm{NH}_{4} \mathrm{OH} \\
\text { Aquadest } \\
\text { Acetic Acid, }\end{array}$ & $\begin{array}{l}\text { Positive, red solution } \\
\text { Positive, exit foam }\end{array}$ \\
\hline 6. & dan & $\begin{array}{l}\text { Sulfuric } \\
\text { Acid conc. }\end{array}$ & Positive, green solution \\
\hline 7. & Tanin & $\mathrm{FeCl}_{3}$ & Positive, black solution \\
\hline
\end{tabular}

Bactericidal Potential (MIC \& MBC) from Powder Extract of Citrus hystrix Leaf for Staphylococcus aureus \& Salmonella typhi

\begin{tabular}{lllll}
\hline $\begin{array}{l}\text { Concentration } \\
\text { of Citrus hystrix } \\
(\mathrm{mg} / \mathrm{mL})\end{array}$ & \multicolumn{2}{l}{ Clarity Level } & \multicolumn{2}{c}{$\begin{array}{c}\text { Colonies after } \\
\text { treatment }\end{array}$} \\
\cline { 2 - 5 } & S. & S. & S. & S. \\
& aureus & typhi & aureus & typhi \\
\hline 90 & & Turbid & & 5 \\
100 & & $\begin{array}{c}\text { Turbid } \\
\text { Turbid }\end{array}$ & 4 \\
110 & & Clear & 2 \\
120 & Turbid & Clear & 130 & 1 \\
130 & Turbid & Clear & 98 & 0 \\
140 & Turbid & Clear & 82 & 0 \\
150 & Turbid & & 54 & \\
160 & Turbid & & 50 & \\
170 & Clear & & 8 & \\
180 & Clear & & 0 & \\
190 & Clear & & 0 & \\
200 & Clear & Clear & 0 & 0 \\
Control $(+)$ & Turbid & Turbid & $\infty$ & $\infty$ \\
Control (-) & Turbid & & & \\
\hline
\end{tabular}


Note : $\infty=($ uncounted $)$

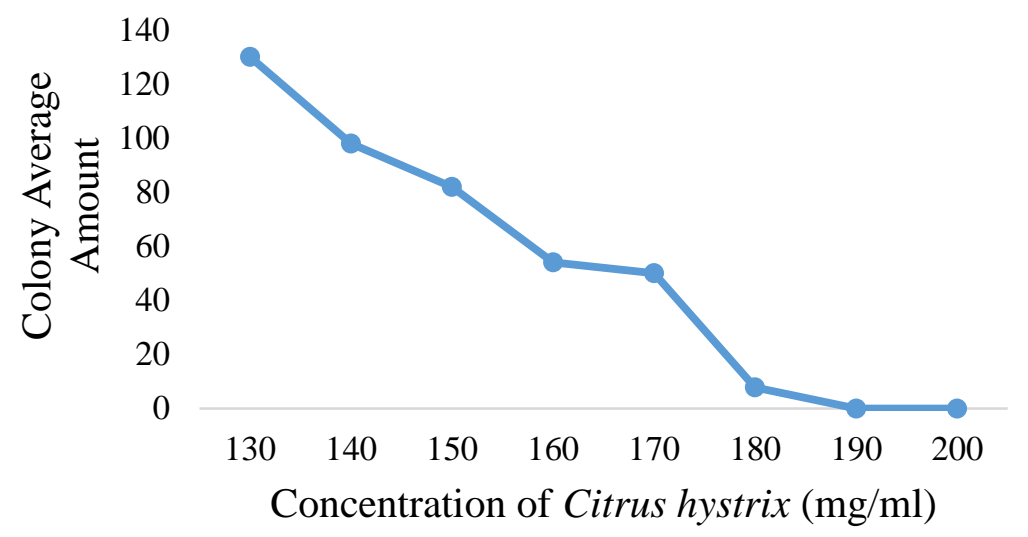

Figure 1. Graph of the average Staphylococcus aureus Colony in every concentration

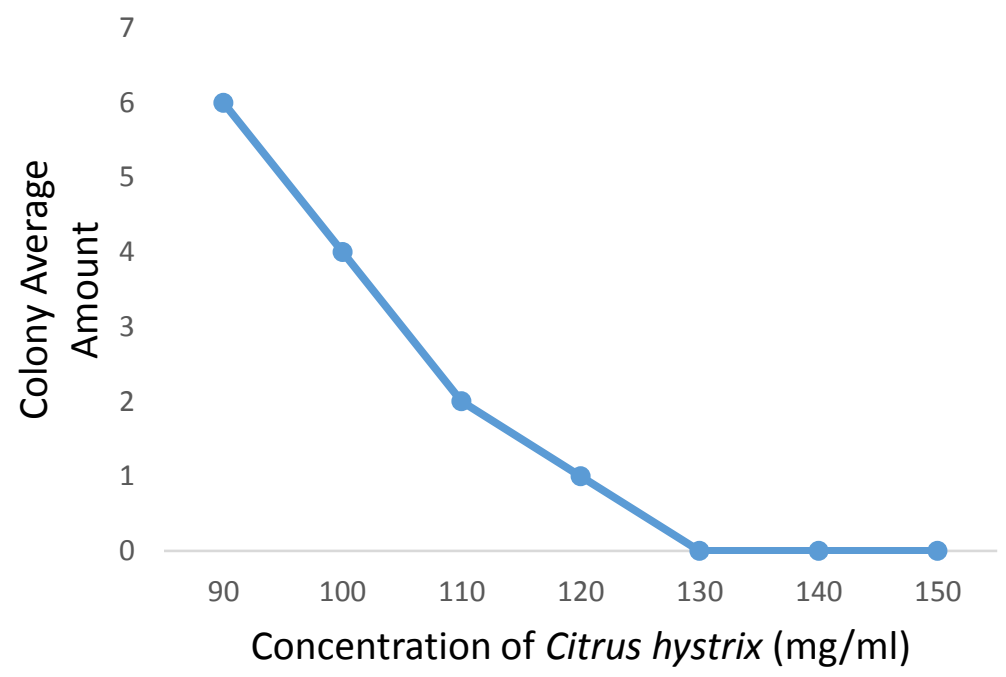

Figure 2. Graph of the average Salmonella typhi Colony in every concentration

The MIC and MBC test results show a higher concentration of Citrus hystrix leaf extract powder is greater the ability to inhibit and kill Staphylococcus aureus and Salmonella typhi. This marked by the occurrence of clarity in the TSB media and a decrease in the number of Staphylococcus aureus and Salmonella typhi colonies in the Nutrient Agar medium. This is influenced by secondary metabolites such as alkaloids, flavonoids, saponins, steroids, triterpenoids, and tannins in the leaves of Citrus hystrix. Alkaloids work on the constituent components of peptidoglycan so that the cell wall layer has not formed intact, the cell dies and inhibits the enzyme topoisomerase ${ }^{20}$. Flavonoids work by damaging cell membranes, followed by the release of intracellular compounds and cell death ${ }^{21}$. Saponin causes the cytoplasm to leak out of the cell resulting in cell death by diffusing through the outer membrane and cell wall to bind to the cytoplasmic membrane. Triterpenoids damage porin so that 
bacterial cells will lack nutrition, stunted growth, or death ${ }^{22}$. Tannins form a polysaccharide complex that can damage cell walls so that metabolism is disrupted and causes cell death ${ }^{23}$.

Bactericidal Potential of Citrus hystrix leaf extract powder to Salmonella typhi (Gram-negative) is better than Staphylococcus aureus (Gram-positive). This can be caused by differences in the structure of the cell wall. The cell wall of gram-positive bacteria consists of several layers of peptidoglycan which form a stable and rigid structure and contains cell wall substance called theatric acid, whereas in gramnegative bacteria consists of one or more thin layers of peptidoglycan and a membrane on the outside of the peptidoglycan layer so that the cell wall Gramnegative bacteria are more susceptible to physical shocks such as antibiotics or other antibacterial agents ${ }^{24}$. Besides, in this study, there were differences in the level of bacterial fertility between Staphylococcus aureus and Salmonella typhi, which were Salmonella typhi when planted on Salmonella Shigella media in order not to flourish.

In the research of Yuliani, et al., regarding the antibacterial activity of essential oils of kaffir lime leaves (Citrus hystrix) against Staphylococcus aureus and Escherichia coli, the result of Minimum Inhibitory Concentration (MIC) of Staphylococcus aureus was $1 \%$ and Escherichia coli $0.0625 \%$. While the Minimum Kill Concentration (MBC) of Staphylococcus aureus is $2 \%$ and Escherichia coli $0.0625 \%$. In this research too, there are similarities with this study where gramnegative bacteria are more effectively inhibited and killed than gram-positive bacteria $^{23}$. While in this study there are differences with research in 2010 regarding the antimicrobial activity test of methanol extract of lime leaves (Citrus aurantifolia, Swingle) against Staphylococcus aureus and Salmonella typhi obtained the Minimum Inhibitory Concentration (MIC) results could not determine due to the turbidity level of each concentration almost the same. While the Minimum Kill Concentration (MBC) of Staphylococcus aureus at concentrations of $0.4 \%$ and $1.6 \%$ for Salmonella typhit ${ }^{16}$.

The difference in results can be caused by the type of plant, media, concentration, method, solvent, and drying material used. It was also seen from the bacteria studied in different organ structures, species, bacterial osmotic pressure, and others. The difference in the results of this study with the research of Yuliani and Frisennia is probably due to the addition of aerosil dryer in making Citrus hystrix leaf extract powder. According to Sembiring, the use of dried extracts can reduce levels of active compounds in plants, so that in this study the concentrations used in inhibiting and killing Staphylococcus aureus and Salmonella typhi are higher than those of Yuliani and Frisennia research ${ }^{25}$.

\section{CONCLUSION}

Citrus hystrix D.C. leaves contain secondary metabolites like alkaloid compounds, saponins, steroids, triterpenoids, tannins, and flavonoids. The MIC of those leaves extract powder against Staphylococcus aureus and Salmonella typhi are $180 \mathrm{mg} / \mathrm{mL}$ and $120 \mathrm{mg} / \mathrm{mL}$, the $\mathrm{MBC}$ are $190 \mathrm{mg} / \mathrm{mL}$ and $130 \mathrm{mg} / \mathrm{mL}$. So Bactericidal Potential of them is started from $190 \mathrm{mg} / \mathrm{mL}$ for Staphylococcus aureus and 130 $\mathrm{mg} / \mathrm{mL}$ for Salmonella typhi.

\section{ACKNOWLEDGES}

The author would like to thank those who have helped to carry out this research, especially for Poltekkes Kemenkes Banjarmasin, Poltekkes Research Unit, and Laboratory in Medical Laboratory Technologist Campus who have facilitated this research. 


\section{CONFLICT OF INTEREST}

The authors declare no conflict of interest and have not received any funds for this study.

\section{REFERENCES}

1. Rifa'i, A., Muhlisin, A., Lutpiatina L. Erythrocyte Morphology of Tuberculosis Patients. Tropical Health and Medical Research. 2019; 1(1): 10-18. https://doi.org/10.35916/thmr.v1i1.3

2. Mustika Sari, P., Lutpiatina, L., Muhlisin. A. Staphylococcus aureus in Traditional Coconut milk Drinks. Tropical Health and Medical Research. 2019; 1(1): 33-38. https://doi.org/10.35916/thmr.v1i1.1

3. Fahani, A., Dwiyanti, RD., Muhlisin. A. Contamination of Bacillus cereus in Elementary School Snack Food. Tropical Health and Medical Research. 2019; 1(2): 56-61. https://doi.org/10.35916/thmr.v1i2.10

4. Kuswiyanto. Bakteriologi 2 Buku Ajar Analis Kesehatan. Jakarta: EGC. 2014. pp. 1-17, 35-44.

5. Kemenkes RI. Profil Kesehatan Indonesia. Jakarta: Kementerian Kesehatan Republik Indonesia. 2016

6. World Health Organization (WHO). Results of the 2017 global WHO survey on yaws. Weekly Epidemiological Record. 2018;93(33):417-28.

7. Pratiwi ST. Mikrobiologi Farmasi. Jakarta: Penerbit Erlangga. 2008

8. Kamienski M. Farmakologi. Yogyakarta: Andi. 2015.

9. Huda, N., Dwiyanti, RD., Thuraidah. A. Effectiveness of Cinnamon (Cinnamomum burmannii) Ethanol Extract Against Staphylococcus aureus Growth. Tropical Health and Medical Research. 2019; 1(2): 39-43. https://doi.org/10.35916/thmr.v1i2.6

10. Mahmudah, S., Muntaha, A., Muhlisin. A. Effectiveness of Dayak (Eleutherine palmifollia (L) Merr) Extracts Against Escherichia Coli In Vitro. Tropical Health and Medical Research. 2019; 1(2): 44-48. https://doi.org/10.35916/thmr.v1i2.8

11. Sutiany, A., Dwiyanti, RD., Oktiyani. N. Inhibition Strength of Rosella (Hibiscus sabdariffa L.) Boiled Water on Salmonella typhi in vitro. Tropical Health and Medical Research. 2019; 1(2): 62-67. https://doi.org/10.35916/thmr.v1i2.7

12. Pratama, HN., Lutpiatina, L., Dwiyanti, RD., Muhlisin. A. Growth of Malassezia furfur in Media with The Addition of Basil (Ocimum basilicum Linn) Powder. Tropical Health and Medical Research. 2020; 2(1): 26-33

13. Kusumawardhani, N., Thuraidah, A., Nurlailah. Citrus hystrix D.C Fluid Inhibits The Growth of Staphylococcus aureus. Tropical Health and Medical Research. 2020; 2(1); 34-38

14. Intarina $\mathrm{H}$. Sehat Alami dengan Herbal 250 Tanaman Herbal Berkhasiat Obat+ 60 resep Menu Kesehatan: Pusat Studi Biofarmasetika, LPPM IPB dan Gagas Ulung. Jakarta: Penerbit PT Gramedia Pustaka Utama Anggota Ikapi. 2014.

15. Irwan A, Mustikasari K, Ariyani D. Chemical Preliminary Evaluation of leaves, Peels, and Fleshs Fruit of Limau Kuit: Local Orange of South Kalimantan. Jurnal Sains dan Terapan Kimia. 2017 Oct 3;11(2):71-9.

16. Frisennia N. Uji Aktivitas Antimikroba Ekstrak Metanol Daun Jeruk Nipis (Citrus Aurantifolia Swingle) Terhadap Beberapa Mikroba Patogen dengan Metode KLTBioautografi (Doctoral dissertation, Univeritas Islam Negeri Alauddin Makassar). 2010; 
17. Yuliani R, Indrayudha P, Rahmi SS. Aktivitas Antibakteri Minyak Atsiri Daun Jeruk Purut (Citrus hystix) terhadap Staphylococcu aureus dan Escherchia coli. Pharmacon. 2011; 12 (2): 50-54.

18. Uda MN, Gopinath SC, Ibrahim NH, Hashim MK, Nuradibah MA, Salimi MN, Shen TE, Fen OY, Akhir MA, Hashim U. Preliminary Studies on Antimicrobial Activity of Extracts from Aloe Vera Leaf, Citrus Hystrix Leaf, Zingiber Officinale and Sabah Snake Grass Against Bacillus Subtilis. InMATEC Web of Conferences 2018 (Vol. 150, p. 06042). EDP Sciences.

19. Sentat T, Pangestu S. Uji Efek Analgesik Ekstrak Etanol Daun kersen (Muntingia calabura L.) pada Mencit Putih Jantan (Mus musculus) dengan Induksi Nyeri Asam Asetat. Jurnal IImiah Manuntung. 2017 Jan 27;2(2):147-53.

20. Kurniawan B, Aryana WF. Binahong (Cassia Alata L) As Inhibitor Of Escherichiacoli Growth. Jurnal Majority. 2015 Jan 25;4(4): 100-104.

21. Omojate Godstime C, Enwa Felix O, Jewo Augustina O, Eze Christopher O. Mechanisms of antimicrobial actions of phytochemicals against enteric pathogens-a review. J Pharm Chem Biol Sci. 2014 Aug;2(2):77-85.

22. Sogandi S. Uji Aktivitas Antibakteri Ekstrak dan Fraksi Daun Jati (Tectona grandiss Linn. F) Dalam Menghambat Pertumbuhan Bakteri Escherichia coli dan Staphylococcus aureus Secara In Vitro. Indonesia Natural Research Pharmaceutical Journal. 2018 Aug 30;3(1):93-105.

23. Nurhalimah H, Wijayanti N, Widyaningsih TD. Efek Antidiare Ekstrak Daun Beluntas (Pluchea indica L.) Terhadap Mencit Jantan Yang Diinduksi Bakteri Salmonella Thypimurium [In Press Juli 2015]. Jurnal Pangan dan Agroindustri. 2014 Oct 8;3(3).

24. Rostinawati T, Suryana S, Fajrin M, Nugrahani H. Aktivitas Antibakteri Ekstrak Etanol Daun Kelakai (Stenochlaena palustris (Burm. F) Bedd) Terhadap Salmonella typhi dan Staphylococcus aureus dengan Metode Difusi Agar CLSI M02-A11. Pharmauho: Jurnal Farmasi, Sains, dan Kesehatan. 2018 Jan 24; 3(1).

25. Sembiring BR. Pengaruh Konsentrasi Bahan Pengisi dan Cara Pengeringan terhadap Mutu Ekstrak Kering Sambiloto. Bul Litro, 2009; Volume 20 (2): 173-181. 